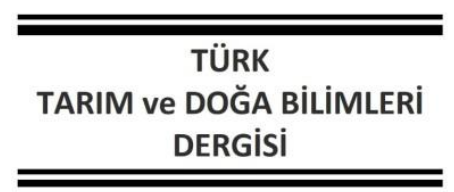

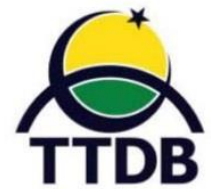

www.dergipark.gov.tr/turkjans
TURKISH

JOURNAL Of AGRICULTURAL and NATURAL SCIENCES

\title{
Research Article \\ Exogenous Silicon Dioxide Treatment in Carrot (Daucus carota L.) Under Salt Stress Conditions
}

\author{
Ayşe Gül NASIRCILAR ${ }^{1 *}$, Kamile ULUKAPI ${ }^{2}$, Hatice ÜSTÜNER ${ }^{3}$
}

${ }^{1}$ Akdeniz University, Faculty of Education, Department of Mathematics and Science Education, Antalya ${ }^{2}$ Akdeniz University, Vocational High School of Technical Sciences, Department of Plant and Animal Production, Antalya

${ }^{3}$ Akdeniz University, Institute of Science, Department of Biology, Antalya

*Sorumlu Yazar: nasircilar@akdeniz.edu.tr

Received: 25.06.2021 Received in revised: 29.09.2021 Accepted: 14.10.2021

\begin{abstract}
In this study, the effects of exogenous silicon dioxide applications $\left(0.5,1,1.5 \mathrm{mM} \mathrm{SiO}_{2}\right)$ on the germination parameters of carrot seeds were investigated under salt stress conditions (150, $200 \mathrm{mM} \mathrm{NaCl}$ ). For this purpose, germination percentage (GP), mean germination time (MGT), germination rate coefficient (CVG), germination rate index (GRI), germination index (GI), seedling viability index (SVI), leaf number, shoot and root lengths $(\mathrm{mm})$ and plant fresh weight $(\mathrm{g})$ were determined. Germination parameters of yellow carrot, sensitive to salt stress, were adversely affected by $150 \mathrm{mM} \mathrm{NaCl}$ application and shoot and root lengths were reduced by $80 \%$. Especially $\mathrm{SiO}_{2}$ applications had a positive effect on germination parameters for the cultivar. In $150 \mathrm{mM}$ $\mathrm{NaCl}$ application, the germination of the seeds treated with $0.5 \mathrm{mM} \mathrm{SiO}_{2}$ increased approximately two times (23\%), and $15 \%$ germination was obtained in $200 \mathrm{mM} \mathrm{NaCl}$, which did not germinate in the control. Although the black carrot cultivar tolerated salt stress, silicon dioxide treatments had a stimulating effect on germination and development. It was determined that especially $1.5 \mathrm{mM} \mathrm{SiO}_{2}$ application in black carrot seeds had a positive effect on germination parameters. Germination percentage increased to $93 \%$ in seeds treated with 1.5 $\mathrm{mM} \mathrm{SiO}_{2}$ in $150 \mathrm{mM} \mathrm{NaCl}$, and $86 \%$ at $200 \mathrm{mM} \mathrm{NaCl}$ concentration, reaching higher values compared to the control group. The results showed that pre-treatment with appropriate silicon concentrations significantly improved germination performance and promoted tolerance to the salt stress.
\end{abstract}

Key words: Carrot, Germination, Salt Stress, Silicon dioxide

\section{Tuz Stresi Koşullarında Havuçta (Daucus carota L.) Eksojen Silikon Dioksit Uygulamaları}

\section{Öz}

Bu çalışmada, tuz stresi koşullarında (150, $200 \mathrm{mM} \mathrm{NaCl})$ havuç tohumlarının çimlenme parametreleri üzerine dışarıdan silikon dioksit uygulamalarının $(0.5,1,1.5 \mathrm{mM} \mathrm{SiO}$ ) etkileri araştırılmıştır. Bu amaçla çimlenme yüzdesi (ÇY), ortalama çimlenme süresi (OÇS), çimlenme oranı katsayısı (ÇOK), çimlenme hız indeksi (ÇHI), çimlenme indeksi (ÇI), fide güç indeksi (FGI), yaprak sayısı, sürgün ve kök uzunluğu (mm) ve bitki taze ağırlı̆ı (g) belirlenmiştir. Tuz stresine duyarlı sarı havucun çimlenme parametreleri $150 \mathrm{mM} \mathrm{NaCl}$ uygulamasından olumsuz etkilenmiş, sürgün ve kök uzunlukları \%80 oranında azalmıştır. Özellikle $\mathrm{SiO}_{2}$ uygulamaları bu çeşit için çimlenme parametrelerini olumlu etkilemiştir. $150 \mathrm{mM} \mathrm{NaCl}$ uygulamasında 0,5 mM $\mathrm{SiO}_{2}$ ile muamele edilen tohumların çimlenmesi yaklaşık iki kat (\%23) artmış ve kontrol grubunda çimlenmenin gerçekleşmediği 200 mM NaCl'de \%15 çimlenme elde edilmiştir. Siyah havuç çeşidi tuz stresini tolere etmesine rağmen, silikon dioksit uygulamalarının çimlenme ve gelişme üzerinde teşvik edici bir etkisi olmuştur. Siyah havuç tohumlarında özellikle $1.5 \mathrm{mM} \mathrm{SiO}$ uygulamasının çimlenme parametrelerine olumlu etki yaptığı belirlenmiştir. 150 mM NaCl'de 1.5 mM SiO 2 ile muamele edilen tohumlarda çimlenme yüzdesi \%93'e, 200 mM $\mathrm{NaCl}$ konsantrasyonunda ise \%86'ya çıkarak kontrol grubuna göre daha yüksek değerlere ulaşmıştır. Sonuçlar, 
uygun SiO2 konsantrasyonları ile ön işlemin çimlenme performansını önemli ölçüde iyileştirdiğini ve tuz stresine toleransı desteklediğini göstermiştir.

Anahtar kelimeler: Çimlenme, Havuç, Silikon dioksit, Tuz Stresi.

\section{Introduction}

The salinity tolerance levels of plants vary according to their developmental stages. For this reason, the tolerance levels of genotypes should be examined at every stage from germination to harvest. The germination stage is very important in that it constitutes the beginning of seedling development. Abiotic stress factors such as salt stress may cause longer germination time or even germination failure depending on the species and genotype. Alongside starting cultivation with tolerant genotypes, increasing seed germination or existing tolerance with exogenous applications is one of the methods that can be applied to deal with salt stress (Hubbard et al., 2012; Haghighi et al., 2012; Bolton and Simon, 2019; Shi et al., 2014). Carrot, a glycophytic plant, is one of the vegetable species that is sensitive to salt stress (Shannon and Grieve, 1998; Bolton and Simon, 2019). Bolton and Simon (2019) determined salt stress tolerance in 294 carrot accessions. According to the absolute decrease values based on parameters such as germination percentage, salt stress index, they stated that $150 \mathrm{mM} \mathrm{NaCl}$ application is suitable for screening the salt stress tolerance in carrots. Similarly, Jahan et al (2019) found that $100 \mathrm{mM}$ and $150 \mathrm{mM} \mathrm{NaCl}$ concentrations significantly declined the vegetative parameters. In addition to the negative effects of salt stress on vegetative parameters, it was determined that the activities of peroxidase (POD), catalase (CAT), and superoxide dismutase (SOD) and total soluble proteins contents decreased in the edible part of carrots, so the nutritional quality was reduced (Bano et al., 2014). This is a very limiting effect in terms of carrot production, which is widely consumed all over the world due to its rich nutrient content.

Silicon, which has positive effects on plant growth and development, is also an element that provides tolerance to different abiotic stresses such as salinity, drought, and heavy metal stress (Ma and Yamaji, 2008). Despite its known benefits in agriculture, agricultural applications of silicon are not common. However, silicon is very important in terms of sustainable agriculture applications and is an alternative to conventional applications (Guntzer et al., 2012). In order to overcome the salt stress, which has a limiting effect on agricultural production, exogenous silicon application has been tried in different plant species and at different stages of development. It has been determined that exogenous silicon application in soybeans under salt stress reduces the negative effects caused by salt stress by regulating the relationship between antioxidants and nitric oxide scavengers. This effect was occurred by regulating the gene activities associated with reactive oxygen and nitrogen derivatives and by reducing the levels of enzymatic and non-enzymatic antioxidants (Chung et al., 2020). Parallel results were also reached in studies conducted on tomato (AlAghabary et al., 2005), barley (Liang et al., 2003), and grapevine rootstock (Soylemezoglu et al., 2009), and the negative effect of salt stress could be partially balanced. The effects of silicon dioxide on germination were mostly determined by using nano-silicon dioxide, but silicon dioxide applications were very limited. Silicon dioxide is known to positively affect the germination performance of the seeds of Glycyrrhiza uralensis (Zhang et al., 2015). The positive effects of $\mathrm{SiO}_{2}$ application on rice germination and growth under drought stress conditions were found. It was also found that antioxidant enzyme activities increased 2-fold compared to control plants (Ali et al., 2021). There is no study in the literature regarding external applications of silicon dioxide in carrots. In this study, the effects of silicon dioxide on germination performance under salt stress conditions were determined in two different varieties of carrot, which is a glycophytic plant.

\section{Materials and Methods}

This research was carried out in the laboratory of Akdeniz University Vocational School of Technical Sciences, Department of Plant and Animal Production in 2021. Two different carrot cultivars (black, yellow) supplied from a commercial company were used as plant material in the research. For surface sterilization, the seeds were kept in $10 \%$ sodium hypochlorite solution for 10 minutes and then rinsed with sterile distilled water 3 times for 5 minutes. In order to determine the effects of silicon dioxide $\left(\mathrm{SiO}_{2}\right)$ on germination under salt stress conditions, seeds were kept in solutions prepared at $0.5,1$ and $1.5 \mathrm{mM} \mathrm{SiO}_{2}$ concentrations for 6 hours in dark condition. Then it was placed on double-layered sterile blotting papers placed on petri plates $(90 \times 15 \mathrm{~mm})$. The seeds were exposed to salt stress by watering with $150 \mathrm{mM} \mathrm{NaCl}$, which was determined as the threshold value in a previous study (Nasircilar et al., 2019), and $200 \mathrm{mM} \mathrm{NaCl}$ concentrations to 
evaluate the effect of more severe salt stress. Control groups were formed by keeping them in distilled water. Experiments were conducted in 4 repetitions and 25 seeds were placed in petri dishes per treatment. The petri plates were maintained to germinate under $24 \pm 1$ 으 temperature and dark conditions. The number of germinated seeds in the days following the experiment was recorded daily and at the end of the experiment, germination percentage (GP), mean germination time (MGT), coefficient of velocity of germination (CVG), germination rate index (GRI), germination index (GI), seedling vigor index (SVI) were calculated. Germination tests were completed in 14 days by applying ISTA rules (ISTA 1985).

GP $(\%)=$ Number of germinated seeds / Total number of seeds $X 100$ (Gosh et al. 2014)

MGT: $\Sigma \mathrm{Dn} / \Sigma \mathrm{n} D=$ days counted from the beginning of the test, $\mathrm{n}=$ number of seeds germinated on day D (Ellis and Roberts, 1981; Sivritepe, 2012).

CVG: $\quad \mathrm{N} 1+\mathrm{N} 2+\ldots .+\mathrm{Nx} / 100 x \mathrm{~N} 1 \mathrm{~T} 1+\ldots . .+\mathrm{NxTx}$ (Kotowski, 1926)

$\mathrm{T}$ : number of days corresponding to $\mathrm{N}, \mathrm{N}$ : number of seed germinated each day 1994)

GRI (\%/day): G1/1+G2/2+......Gx/x (Esechie,

G1: Germination percentage $\times 100$ at the first day after sowing, G2: Germination percentage x100 at the second day after sowing, GI: (14xn1) + $(13 \times n 2)+\ldots . .+(1 \times n 14)$

$n 1, n 2, \ldots, n 14:$ number of germinated seeds on the first, second and subsequent days until the 14 th; $14,13 . .$. , and 1 are weights given to the number of germinted seeds on the first, second and subsequent days respectively (modified from Benech et al., 1991).
SVI $=$ [Seedling length $(\mathrm{cm}) \times$ GP $(\%)]($ Baki and Anderson, 1973)

The emergence of the radicle $(1 \mathrm{~mm})$ from the testa was taken as a basis for germination, and after germination, the experiments were continued in the same temperature plant growth room with a light/dark photoperiod of $16 / 8$ hours. During the experiment, $3 \mathrm{ml}$ irrigation was done each time considering the drying condition of the filter papers. Trials for vegetative parameters were continued for 21 days, and at the end of this period, shoot length $(\mathrm{cm})$, root length $(\mathrm{cm})$, plant fresh weight $(\mathrm{g})$ were measured and the number of leaves was determined.

The obtained data were evaluated to statistical analysis with the MINITAB 17 package program, vegetative growth parameters were evaluated by analysis of variance, and differences were determined by Tukey test. The evaluation and comparison of the confidence intervals of the mean of the data of germination parameters were made with Interval Plot (Minitab).

\section{Results and Discussion}

Germination, which is the first stage of plant growing, is adversely affected by abiotic stress factors, including salt stress. Therefore, in this study, the effects of silicon dioxide pre-treatments were investigated to reduce the effects of salt stress on the carrot which is a glycophytic plant (Bolton and Simone, 2019) during the germination period. The variance analysis results regarding the number of leaves, shoot length, root length and plant fresh weight were given in Table 1. As seen, sources of variation on shoot length, root length, plant weight and leaf number were found statistically significant at 0.01 level (Table 1 ). Only the effect of the cultivar on the leaf number was determined to be 0.05 significant level

Table 1. Variance analysis result with respect to the number of leaves, shoot length, root length and plant fresh weight of carrot cultivars

\begin{tabular}{|c|c|c|c|c|c|}
\hline Variation source & $\mathrm{df}$ & Leaf number & Shoot length (mm) & Root length (mm) & Plant weight (g) \\
\hline Cultivar (C) & 1 & $*$ & $* *$ & $* *$ & $* *$ \\
\hline Salt (S) & 2 & $* *$ & $* *$ & $* *$ & $* *$ \\
\hline $\mathrm{SiO}_{2}$ & 3 & $* *$ & $* *$ & $* *$ & $* *$ \\
\hline $\mathrm{CxS}$ & 2 & $* *$ & $* *$ & $* *$ & $* *$ \\
\hline $\mathrm{C} \times \mathrm{SiO}_{2}$ & 3 & $* *$ & $* *$ & $* *$ & $* *$ \\
\hline $\mathrm{Sx} \mathrm{SiO}_{2}$ & 5 & $* *$ & $* *$ & $* *$ & $* *$ \\
\hline $\mathrm{CxSx} \mathrm{SiO}_{2}$ & 11 & $* *$ & $* *$ & $* *$ & $* *$ \\
\hline
\end{tabular}

Distinct letters in the row indicate significant differences according to Tukey's test $(p<0.05) .{ }^{*}, * *$ Significant at $p<0.05$ and $p<0.01$, respectively. ns: Nonsignificant. df: degrees of freedom

Table 2 was represented the effects of salt stress and $\mathrm{SiO}_{2}$ applications on the number of leaves, shoot and root length, and plant weight of carrot cultivars. It was determined that the Yellow cultivar, which did not germinate at $200 \mathrm{mM} \mathrm{NaCl}$, was more sensitive to salt stress. Germination occurred in the seeds treated with $\mathrm{SiO}_{2}$ at $200 \mathrm{mM}$ $\mathrm{NaCl}$, and the plants developed tolerance to salt 
stress. It was determined that 0.5 and $1 \mathrm{mM} \mathrm{SiO}_{2}$ application results gave approximately the same results as the control group, and $1 \mathrm{mM} \mathrm{SiO}_{2}$ application gave better results than the control group in terms of shoot length $(21.43 \mathrm{~mm})$ and plant weight $(0.0963 \mathrm{~g})$. When the results of plants exposed to salt stress were compared, $\mathrm{SiO}_{2}$ applications at $150 \mathrm{mM} \mathrm{NaCl}$ were included in the same statistical group in terms of leaf number, shoot and root length, on the other hand, it was determined that plant fresh weights increased with $\mathrm{SiO} 2$ application and $1.5 \mathrm{mM} \mathrm{SiO}_{2}$ gave the best results $(0.0945 \mathrm{~g})$. Under more severe salt stress conditions $(200 \mathrm{mM} \mathrm{NaCl})$, the best results were obtained in the $0.5 \mathrm{mM} \mathrm{SiO}_{2}$ treated group. The fact that the results obtained are in the same statistical group as the control group or have reached very close values shows that $0.5 \mathrm{mM} \mathrm{SiO}_{2}$ application at $200 \mathrm{mM}$ salt stress is quite effective. In the Black cultivar, the control group was in the same statistical group with 150 and $200 \mathrm{mM}$ $\mathrm{NaCl}$ applications, which shows that this cultivar is quite tolerant to salt stress. In addition, $\mathrm{SiO}_{2}$ applications also increased the development of plants. The highest growth values under salt stress conditions were at both $150 \mathrm{mM}$ (leaf number: 6, shoot length: $40.38 \mathrm{~mm}$, root length: $79.00 \mathrm{~mm}$, plant fresh weight: $0.1195 \mathrm{~g}$ ) and $200 \mathrm{mM}$ (leaf number: 6, shoots length: $39.80 \mathrm{~mm}$, root length: $77.88 \mathrm{~mm}$, plant fresh weight: $1.1218 \mathrm{~g})$ was obtained in $1.5 \mathrm{mM} \mathrm{SiO}_{2}$ treatment.

Table 2. Effect of salt stress and $\mathrm{SiO}_{2}$ on the number of leaves, shoot and root length, and plant fresh weight of carrot cultivars.

\begin{tabular}{|c|c|c|c|c|c|}
\hline Cultivar & Treatment & $\begin{array}{l}\text { Leaf } \\
\text { number } \\
\text { per plant }\end{array}$ & $\begin{array}{l}\text { Shoot length } \\
(\mathrm{mm})\end{array}$ & $\begin{array}{l}\text { Root length } \\
(\mathrm{mm})\end{array}$ & $\begin{array}{l}\text { Plant fresh } \\
\text { weight } \\
\text { (g/plant) }\end{array}$ \\
\hline \multirow[t]{12}{*}{ Yellow } & Control & $6 \mathrm{a}$ & $20.05 \mathrm{ab}$ & $79.78 \mathrm{a}$ & $0.0795 \mathrm{bc}$ \\
\hline & $150 \mathrm{mM} \mathrm{NaCl}$ & $2 b$ & $5.25 \mathrm{c}$ & $18.58 \mathrm{~b}$ & $0.0770 \mathrm{c}$ \\
\hline & $200 \mathrm{mM} \mathrm{NaCl}$ & 0 & 0.00 & 0.00 & 0.0000 \\
\hline & $0.5 \mathrm{mM} \mathrm{Si}$ & $6 a$ & $21.08 \mathrm{ab}$ & $80.50 \mathrm{a}$ & $0.0890 \mathrm{abc}$ \\
\hline & $0.5 \mathrm{mM} \mathrm{Si}+150 \mathrm{mM} \mathrm{NaCl}$ & $2 b$ & $5.43 \mathrm{c}$ & $18.70 \mathrm{~b}$ & $0.0888 \mathrm{abc}$ \\
\hline & $0.5 \mathrm{mM} \mathrm{Si}+200 \mathrm{mM} \mathrm{NaCl}$ & $6 a$ & $20.38 \mathrm{ab}$ & $80.68 \mathrm{a}$ & $0.0853 a b c$ \\
\hline & $1 \mathrm{mM} \mathrm{Si}$ & $6 a$ & $21.43 \mathrm{a}$ & $81.43 \mathrm{a}$ & $0.0963 \mathrm{a}$ \\
\hline & $1 \mathrm{mM} \mathrm{Si+150mM} \mathrm{NaCl}$ & $2 b$ & $5.10 \mathrm{c}$ & $18.98 \mathrm{~b}$ & $0.0910 a b c$ \\
\hline & $1 \mathrm{mM} \mathrm{Si}+200 \mathrm{mM} \mathrm{NaCl}$ & 0 & 0.00 & 0.00 & 0.0000 \\
\hline & $1.5 \mathrm{mM} \mathrm{Si}$ & $2 b$ & $5.43 \mathrm{c}$ & $19.25 \mathrm{~b}$ & $0.0920 a b c$ \\
\hline & $1.5 \mathrm{mM} \mathrm{Si}+150 \mathrm{mM} \mathrm{NaCl}$ & $2 b$ & $5.58 \mathrm{c}$ & $19.28 \mathrm{~b}$ & $0.0945 \mathrm{ab}$ \\
\hline & $1.5 \mathrm{mM} \mathrm{Si}+200 \mathrm{mM} \mathrm{NaCl}$ & $2 b$ & $4.50 \mathrm{c}$ & $14.48 \mathrm{~b}$ & $0.0383 \mathrm{~d}$ \\
\hline \multirow[t]{12}{*}{ Black } & Control & $2 \mathrm{c}$ & $16.13 c$ & $46.48 b$ & $0.0723 \mathrm{~b}$ \\
\hline & $150 \mathrm{mM} \mathrm{NaCl}$ & $2 c$ & $16.00 \mathrm{c}$ & $45.85 b$ & $0.0710 \mathrm{~b}$ \\
\hline & $200 \mathrm{mM} \mathrm{NaCl}$ & $2 c$ & $16.23 \mathrm{c}$ & $46.60 \mathrm{~b}$ & $0.0680 \mathrm{~b}$ \\
\hline & $0.5 \mathrm{mM} \mathrm{Si}$ & $6 a$ & $41.18 \mathrm{a}$ & $78.25 \mathrm{a}$ & $0.1120 \mathrm{a}$ \\
\hline & $0.5 \mathrm{mM} \mathrm{Si}+150 \mathrm{mM} \mathrm{NaCl}$ & $4 \mathrm{~b}$ & $19.58 \mathrm{~b}$ & $79.15 \mathrm{a}$ & $0.8075 \mathrm{~b}$ \\
\hline & $0.5 \mathrm{mM} \mathrm{Si}+200 \mathrm{mM} \mathrm{NaCl}$ & $4 \mathrm{~b}$ & $10.13 \mathrm{~d}$ & $29.75 c$ & $0.0700 \mathrm{~b}$ \\
\hline & $1 \mathrm{mM} \mathrm{Si}$ & $4.5 \mathrm{~b}$ & $39.85 \mathrm{a}$ & $81.08 \mathrm{a}$ & $0.1070 \mathrm{a}$ \\
\hline & $1 \mathrm{mM} \mathrm{Si}+150 \mathrm{mM} \mathrm{NaCl}$ & $2 c$ & $16.28 \mathrm{bc}$ & $45.73 b$ & $0.0750 \mathrm{~b}$ \\
\hline & $1 \mathrm{mM} \mathrm{Si}+200 \mathrm{mM} \mathrm{NaCl}$ & $2 c$ & $15.30 \mathrm{c}$ & $46.23 \mathrm{~b}$ & $0.0648 \mathrm{~b}$ \\
\hline & $1.5 \mathrm{mM} \mathrm{Si}$ & $4 b$ & $39.90 \mathrm{a}$ & $78.90 \mathrm{a}$ & $0.1188 \mathrm{a}$ \\
\hline & $1.5 \mathrm{mM} \mathrm{Si}+150 \mathrm{mM} \mathrm{NaCl}$ & $6 a$ & $40.38 \mathrm{a}$ & $79.00 \mathrm{a}$ & $0.1195 \mathrm{a}$ \\
\hline & 1.5mM Si+200mM NaCl & $6 \mathrm{a}$ & $39.80 \mathrm{a}$ & $77.88 \mathrm{a}$ & $1.1218 \mathrm{a}$ \\
\hline
\end{tabular}

Distinct letters in the row indicate significant differences according to Tukey's test $(p \leq 0.05)$. 
When the data in Table 2 were examined, it was determined that the values obtained as a result of $\mathrm{SiO}_{2}$ applications were higher than the control and that the $\mathrm{SiO}_{2}$ application stimulated plant growth in the severe salt stress conditions of the Black cultivar. The results obtained in maize (Sun et al., 2021) revealed that $\mathrm{SiO}_{2}$ can have positive effects on some parameters that may negatively affect both germination and seedling growth such as breaking seed dormancy, restoring seed viability, and improving storage damage. The curative effect of $\mathrm{SiO}_{2}$ on plant growth under plant salt stress conditions in soybean (Lee et al., 2010) was explained by increasing endogenous gibberellin levels and decreasing abscisic acid and proline levels as a result of $\mathrm{SiO}_{2}$ applications. In addition, it has been determined that exogenous $\mathrm{SiO}_{2}$ applications have an amelioration effect on plant development as a result of salt stress by increasing antioxidant enzyme activities and chlorophyll content in tomato (Al-aghabary et al., 2005), and by regulating photosynthetic parameters such as chlorophyll content, transpiration rate, and stomatal conductivity in two legume cultivars (Murillo-Amador et al., 2007).

Studies on salt stress tolerance of carrots during germination are very limited and increasing salt concentrations result in a decrease in both the total number of germinated seeds and the germination rate (Bolton and Simone, 2019). In Figure 1 and 2, the GP, MTG, CVG, GRI, GI, and SVI of carrot varieties treated with salt stress and $\mathrm{SiO}_{2}$ are presented as an interval plot. The highest germination percentage in both cultivars was obtained from the control group (yellow: 73\%; black: 78\%), and this rate increased with $\mathrm{SiO}_{2}$ treatment in the black cultivar $(97 \%$ at $0.5 \mathrm{mM}$ $\mathrm{SiO}_{2}$ ). Salt stress caused a decrease in germination percentages. Any germination could not be obtained in the yellow variety at $200 \mathrm{mM}$, while this rate was $48 \%$ in the black variety at the same concentration. The increasing effect of $\mathrm{SiO}_{2}$ treatments on germination percentages differed according to the cultivars. $0.5 \mathrm{mM} \mathrm{SiO}_{2}$ application for yellow cultivar and $1.5 \mathrm{mM}$ for black cultivar gave the best results at $150 \mathrm{mM}$ salt concentration and $23 \%$ and $93 \%$ germination rates were obtained respectively. $1.5 \mathrm{mM} \mathrm{SiO}_{2}$ application had a stimulating effect on germination for both cultivars at $200 \mathrm{mM}$ salt concentration and germination rates were $15 \%$ in yellow and $86 \%$ in black cultivar. It was determined that the MGT value decreased considerably as a result of $\mathrm{SiO}_{2}$ applications in saline conditions. Especially in the presence of 200 $\mathrm{mM} \mathrm{NaCl}$, the MGT value was determined as 2.25 in yellow carrots and 7.22 in black carrots after $1.5 \mathrm{mM} \mathrm{SiO}_{2}$ application. It was found that $1.5 \mathrm{mM}$ $\mathrm{SiO} 2$ application increased the CVG value in black carrot cultivar (38.73 in 150 mM, 33.54 in 200 mM $\mathrm{NaCl}$ ). The $\mathrm{GRI}$ value, which reflects the germination percentage, increased with $\mathrm{Si}$ application. The application of $0.5 \mathrm{mM} \mathrm{SiO}_{2}$ for the yellow cultivar and $1.5 \mathrm{mM} \mathrm{SiO}_{2}$ for the black cultivar $(93.00$ at $150 \mathrm{mM} \mathrm{NaCl}, 86.00$ at $200 \mathrm{mM}$ $\mathrm{NaCl}$ ) came forward. $\mathrm{Gl}$ values, which are an indicator of germination rate and percentage, were also positively affected by $\mathrm{SiO}_{2}$ treatment. While the results differed according to the severity of salt stress in the yellow cultivar, $1.5 \mathrm{mM} \mathrm{SiO}_{2}(182.50$ for $150 \mathrm{mM} \mathrm{NaCl}$; 167.25 for $200 \mathrm{mM} \mathrm{NaCl}$ ) was found to be effective in the black cultivar. SVI values, which decreased under salt stress, increased in $\mathrm{SiO}_{2}$ applied groups. $0.5 \mathrm{mM} \mathrm{SiO} 2$ (5.53, $150 \mathrm{mM} \mathrm{NaCl}$; 15.25, $200 \mathrm{mM} \mathrm{NaCl}$ ) in yellow $\mathrm{cv}$ and $1.5 \mathrm{mM} \mathrm{SiO}_{2}$ application in black $\mathrm{cv}$ (111.05 for $150 \mathrm{mM} \mathrm{NaCl}$; 101.18 for $200 \mathrm{mM}$ $\mathrm{NaCl}$ ) gave better results.

In maize (Sun et al., 2021), $\mathrm{SiO}_{2}$ had an improving effect on the germination rate, germination potential, germination index, and vigor index, which are important germination parameters for all plants. Pre-treatment with $\mathrm{SiO}_{2}$ significantly increased germination of rice under drought stress conditions. The applied $\mathrm{SiO}_{2}$ had a stimulating effect on germination by regulating antioxidant enzyme activities, total soluble sugar and proline content (Ali et al., 2021). Similarly, it was stated that the application of $\mathrm{SiO}_{2}$ in tomato (Shi et al., 2014) and lettuce (Alves et al., 2020) improved germination depending on the antioxidant enzyme activity. Supporting the results of this study, it was determined that $\mathrm{SiO}_{2}$ applications promoted germination in wheat (Feghhenabi et al., 2020), maize (Khan et al., 2015) and cucumber (Gou et al., 2020) under salt stress conditions. In addition, studies on arsenic stress (Zia et al., 2017) and drought stress (Ali et al., 2021) are important in terms of showing the positive effect of silicon on germination under different stress conditions. 

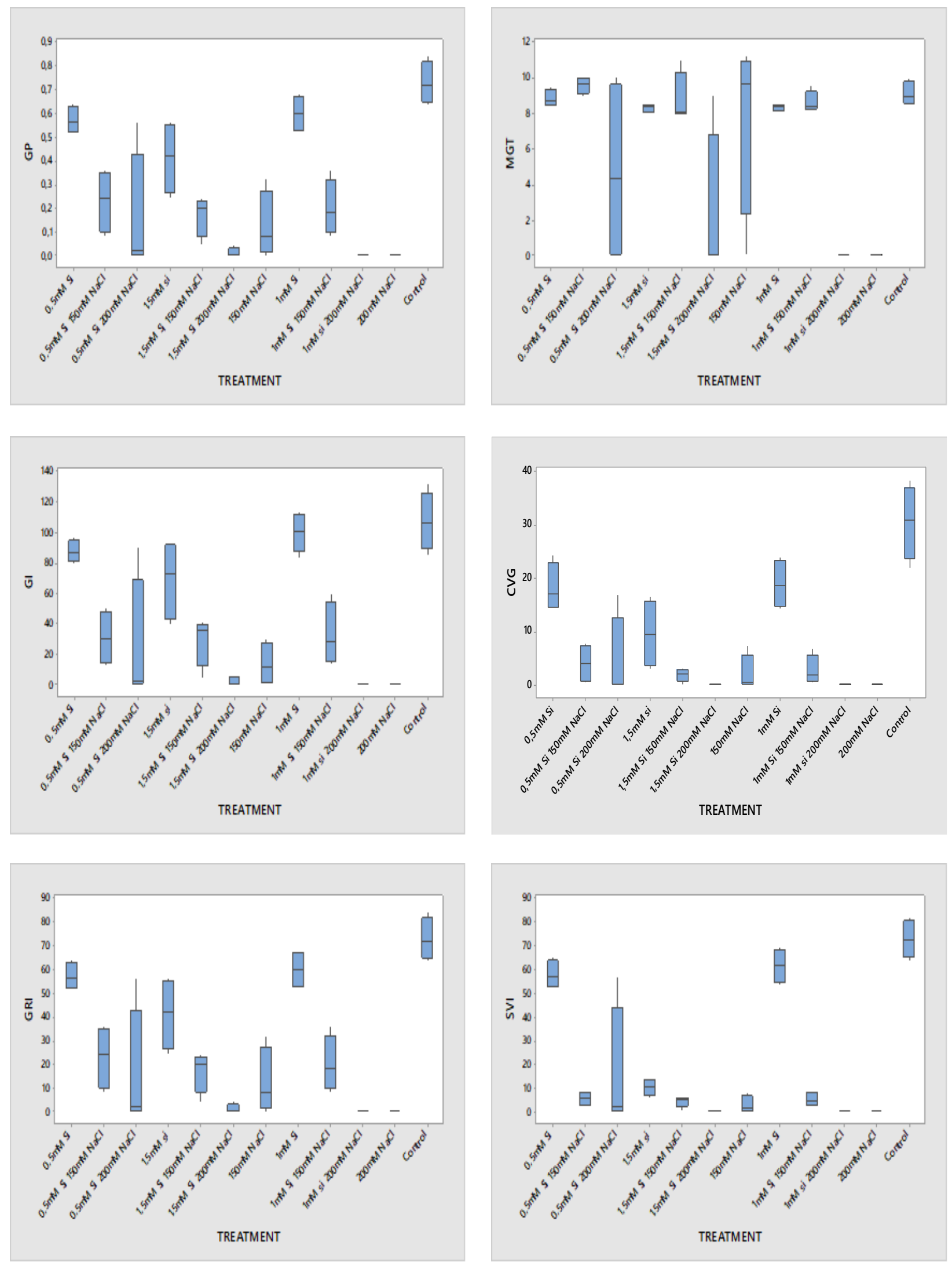

Figure 1. Interval plots of the effect of salt stress and $\mathrm{SiO}_{2}$ applications on germination parameters (GP, MGT, CVG, GRI, GI, SVI) of Yellow carrot cultivar. 

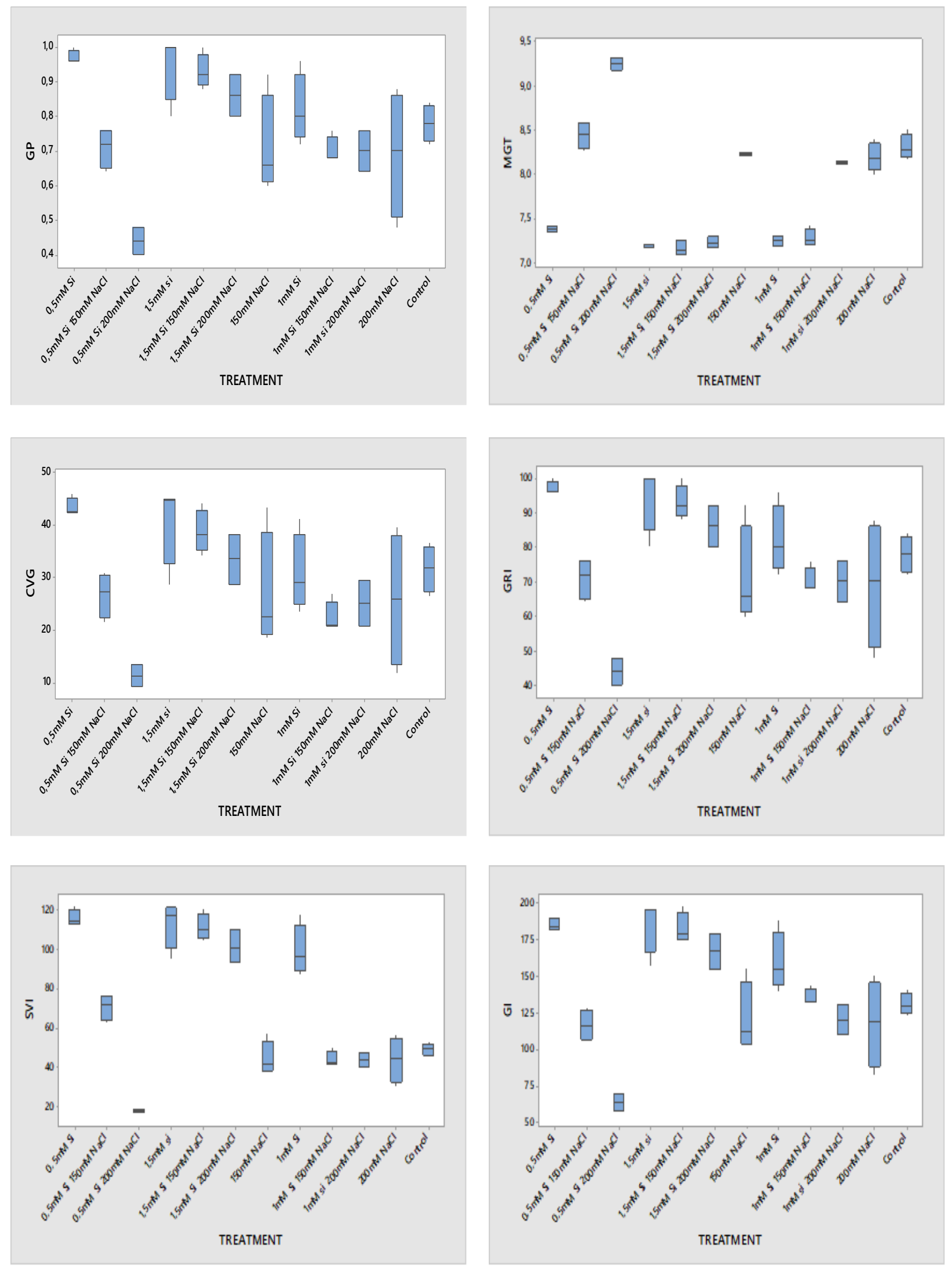

Figure 2. Interval plots of the effect of salt stress and $\mathrm{SiO}_{2}$ applications on germination parameters (GP, MGT, CVG, GRI, GI, SVI) of Black carrot cultivar

\section{Conclusion}


External application of $\mathrm{SiO}_{2}$ had a positive effect on the germination parameters of the carrot, which is a glycophytic plant. It was determined that $\mathrm{SiO}_{2}$ application increased germination percentage, decreased germination time and increased seedling strength depending on genotype. In the yellow cultivar, although no germination occurred in the control group at 200 $\mathrm{mM} \mathrm{NaCl}$, germination was also obtained at this concentration as a result of $\mathrm{SiO}_{2}$ application. The application of $1.5 \mathrm{mM} \mathrm{SiO}_{2}$ was effective on the germination parameters of the black carrot cultivar, which is more tolerant to salt stress. As a result, it has been revealed that the application of $\mathrm{SiO}_{2}$ as a pre-treatment helps to alleviate the negative effects of salt stress in carrots. This study, in which exogenous $\mathrm{SiO}_{2}$ application is made in order to develop tolerance to salt stress in carrots, is expected to be a resource for researchers who will work on this subject.

Conflict of Interest Statement: The authors of the article declare that there is no conflict of interest between them.

Researchers' Contribution Rate Statement: The authors declare that they have contributed equally to the article.

\section{References}

Al-aghabary, K., Zhu Z. and Shi Q. 2005. Influence of silicon supply on chlorophyll content, chlorophyll fluorescence, and antioxidative enzyme activities in tomato plants under salt stress. Journal of Plant Nutrition, 27(12): 2101-2115.

Ali, L. G., Nulit, R., Ibrahim, M. H. and Yien, C. Y. S. 2021. Potassium nitrate and silicon dioxide priming improve germination, seedling growth and protective enzymes of rice var. FARO44 under drought. Journal of Plant Nutrition, 1-14.

Alves, R. D. C., Nicolau, M. C. M., Checchio, M. V., Sousa Junior, G. D. S., Oliveira, F. D. A. D., Prado, R. M. and Gratão, P. L. 2020. Salt stress alleviation by seed priming with silicon in lettuce seedlings: an approach based on enhancing antioxidant responses. Bragantia, (AHEAD).

Baki, A.A. and Anderson, J. D. 1973. Vigour determination in soybean by multiple criteria. Crop Sci 13:630-633

Bano, S., Ashraf, M. and Akram, N. A. 2014. Salt stress regulates enzymatic and nonenzymatic antioxidative defense system in the edible part of carrot (Daucus carota
L.). Journal of Plant Interactions, 9(1): 324329.

Benech Arnold, R. L., Fenner, M. and Edwards, P. J. 1991. Changes in germinability, ABA content and $A B A$ embryonic sensitivity in developing seeds of Sorghum bicolor (L.) Moench. induced by water stress during grain filling. New Phytologist, 118(2): 339-347.

Bolton, A. and Simon, P. 2019. Variation for salinity tolerance during seed germination in diverse carrot [Daucus carota (L.)] germplasm. HortScience, 54(1): 38-44.

Chung, Y. S., Kim, K. S., Hamayun, M. and Kim, Y. 2020. Silicon confers soybean resistance to salinity stress through regulation of reactive oxygen and reactive nitrogen species. Frontiers in Plant Science, 10: 1725.

Ellis, R. H. and Roberts, E. H. 1981. The Quantification of Ageing and Survival in Orthodox Seeds. Seed Science and Technology, 9: 373-409.

Esechie, H. A. 1994. Interaction of salinity and temperature on the germination of sorghum. Journal of Agronomy and Crop Science, 172(3): 194-199.

Feghhenabi, F., Hadi, H., Khodaverdiloo, H. and van Genuchten, M. T. 2020. Seed priming alleviated salinity stress during germination and emergence of wheat (Triticum aestivum L.). Agricultural Water Management, 231: 106022.

Gosh, P., Dash, P. K., Rituraj, S. and Mannan, M. A. 2014. Effect of salinity on germination, growth and yield of radish (Raphanus sativus L.) varieties. International Journal of Biosciences, 5(1): 37-48.

Gou, T., Chen, X., Han, R., Liu, J., Zhu, Y. and Gong, H. 2020. Silicon can improve seed germination and ameliorate oxidative damage of bud seedlings in cucumber under salt stress. Acta Physiologiae Plantarum, 42(1): 1-11.

Guntzer, F., Keller, C. and Meunier, J. D. 2012. Benefits of plant silicon for crops: a review. Agronomy for Sustainable Development, 32(1): 201-213.

Haghighi, M., Afifipour, Z. and Mozafarian, M. 2012. The alleviation effect of silicon on seed germination and seedling growth of tomato under salinity stress. Vegetable Crops Research Bulletin, 76: 119.

Hubbard, M., Germida, J. and Vujanovic, V. 2012. Fungal endophytes improve wheat seed germination under heat and drought stress. Botany, 90(2): 137-149.

ISTA 1985. International Rules for Seed Testing. Seed Science Technology 13. 
Jahan, I., Hossain, M. M. and Karim, M. R. 2019. Effect of salinity stress on plant growth and root yield of carrot. Progressive Agriculture, 30(3): 263-274.

Khan, W. U. D., Aziz, T., Waraich, E. A. and Khalid, M. 2015. Silicon application improves germination and vegetative growth in maize grown under salt stress. Pakistan Journal of Agricultural Sciences, 52(4): 937-944.

Kotowski, F. 1926. Temperature relations to germination of vegetable seed. Proceedings of the American Society for Horticultural Science, 23: 176-184.

Lee, S. K., Sohn, E. Y., Hamayun, M., Yoon, J. Y. and Lee, I. J. 2010. Effect of silicon on growth and salinity stress of soybean plant grown under hydroponic system. Agroforestry systems, 80(3): 333-340.

Liang, Y., Chen, Q., Liu, Q., Zhang, W. and Ding R. 2003. Exogenous silicon (Si) increases antioxidant enzyme activity and reduces lipid peroxidation in roots of saltstressed barley (Hordeum vulgare L.). Journal of Plant Physiology, 160: 1157-1164.

Ma, J. F. and Yamaji, N. 2008. Functions and transport of silicon in plants. Cellular and Molecular Life Sciences, 65(19): 3049-3057.

Murillo-Amador, B., Yamada, S., Yamaguchi, T., Rueda-Puente, E., Ávila-Serrano, N., GarcíaHernández, J. L., ... and Nieto-Garibay, A. 2007. Influence of calcium silicate on growth, physiological parameters and mineral nutrition in two legume species under salt stress. Journal of Agronomy and Crop Science, 193(6): 413-421.

Nasircilar A.G., Ulukapi K. and Kurt Z. 2019. Determination of Salt Tolerance Levels of Carrot (Daucus carota L.) Cultivars and Effects of Salicylic Acid Application on Germination Parameters in Saline
Conditions, 1th International Congress of the Turkish Journal of Agriculture-Food Science and Technology, Antalya, vol.1, pp.145-152.

Shannon, M. and Grieve, C. 1998. Tolerance of vegetable crops to salinity. Scientia Horticulturae, 78(1-4): 5-38.

Shi, Y., Zhang, Y., Yao, H., Wu, J., Sun, H. and Gong, H. 2014. Silicon improves seed germination and alleviates oxidative stress of bud seedlings in tomato under water deficit stress. Plant Physiology and Biochemistry, 78: 27-36.

Sivritepe, H. Ö. 2012. Tohum Gücünün Değerlendirilmesi. Alatarım Dergisi, 11(2): 33-44.

Soylemezoglu, G., Demir, K., Inal, A. and Gunes, A. 2009. Effect of silicon on antioxidant and stomatal response of two grapevine (Vitis vinifera L.) rootstocks grown in boron toxic, saline and boron toxic-saline soil. Scientia Horticulturae, 123: 240-246.

Sun, Y., Xu, J., Miao, X., Lin, X., Liu, W. and Ren, H. 2021. Effects of exogenous silicon on maize seed germination and seedling growth. Scientific Reports, 11(1): 1-13.

Zhang, X. H., Zhou, D., Cui, J. J., Ma, H. L., Lang, D. Y., Wu, X. L., ... and Li, M. 2015. Effect of silicon on seed germination and the physiological characteristics of Glycyrrhizauralensis under different levels of salinity. The Journal of Horticultural Science and Biotechnology, 90(4): 439-443.

Zia, Z., Bakhat, H. F., Saqib, Z. A., Shah, G. M., Fahad, S., Ashraf, M. R., ... and Shahid, M. 2017. Effect of water management and silicon on germination, growth, phosphorus and arsenic uptake in rice. Ecotoxicology and Environmental Safety, 144: 11-18. 